\title{
Effects of Commercial Inorganic and Hog Waste Organic Fertilizer on the Growth Performance and Yield of Pechay (Brassica rapa)
}

\author{
Marivel B. Go ${ }^{1}$, Rodolfo A. Golbin Jr. 2, , Feliciana G. Cababat ${ }^{3}$, Severina P. Velos ${ }^{2}$, Johnry P. Dayupay ${ }^{3}$, \\ Alexis P. Ramirez ${ }^{3}$, Kent Marcial Catubis ${ }^{4}$ \\ ${ }^{1}$ College of Technology, Cebu Technological University, Moalboal Campus, Moalboal, Cebu 6032, Philippines \\ ${ }^{2}$ Graduate School Department, Cebu Technological University, Moalboal Campus, Moalboal, Cebu 6032, Philippines \\ ${ }^{3}$ College of Education, Cebu Technological University, Moalboal Campus, Moalboal, Cebu 6032, Philippines \\ ${ }^{4}$ College of Agriculture, Cebu Technological University, Tuburan Campus, Tuburan, Cebu 6043, Philippines
}

Received September 14, 2021; Revised November 5, 2021; Accepted November 21, 2021

\section{Cite This Paper in the following Citation Styles}

(a): [1] Marivel B. Go, Rodolfo A. Golbin Jr., Feliciana G. Cababat, Severina P. Velos, Johnry P. Dayupay, Alexis P. Ramirez, Kent Marcial Catubis, "Effects of Commercial Inorganic and Hog Waste Organic Fertilizer on the Growth Performance and Yield of Pechay (Brassica rapa)," Universal Journal of Agricultural Research, Vol. 9, No. 6, pp. 248 257, 2021. DOI: 10.13189/ujar.2021.090603.

(b): Marivel B. Go, Rodolfo A. Golbin Jr., Feliciana G. Cababat, Severina P. Velos, Johnry P. Dayupay, Alexis P. Ramirez, Kent Marcial Catubis (2021). Effects of Commercial Inorganic and Hog Waste Organic Fertilizer on the Growth Performance and Yield of Pechay (Brassica rapa). Universal Journal of Agricultural Research, 9(6), 248 - 257. DOI: 10.13189/ujar.2021.090603.

Copyright $(2021$ by authors, all rights reserved. Authors agree that this article remains permanently open access under the terms of the Creative Commons Attribution License 4.0 International License

\begin{abstract}
This study compares the effect of Hog Waste Organic Fertilizer (HWOF) and Commercial Inorganic Fertilizer (CIF) on the growth performance of pechay (Brassica rapa) in 7 Treatments: T1- pure soil; T2 - soil with CIF; T3- $20 \%$ hog waste; T4 - 40\% hog waste; T5 - $60 \%$ hog waste; T6 - $80 \%$ hog waste; T7 - 100\% hog waste. The experiment for 30 days was performed on a randomized complete block design (RCBD). The data gathered were analyzed using one-way ANOVA to determine the differences among the growth performances of pechay based on height, leaf width, no. of leaves, weight, and root length. The results present the physico-chemical analyses of both soil and hog waste fertilizers. Regarding the growth performances of pechay (Brassica rapa), T5 obtained the highest plant height $108.27 \mathrm{~cm}$ and leaf width $-112.07 \mathrm{~cm}$, which were significantly higher than T2 using CIF. The highest weight gain was obtained by T6, which was significantly higher than the other treatments followed by T5, but both were comparable to the samples of CIF, while $\mathrm{T} 3$ obtained the longest root length. Thus, the application of $60 \%$ to $80 \%$ HWOF yields comparable results with CIF. Hence, such application is recommended for community organic
\end{abstract}

farming.

Keywords Organic Fertilizer, Hog Waste, Pechay, Inorganic Fertilizer, Physico-Chemical Analyses

\section{Introduction}

Livestock production continues to be an essential part of the global agricultural system as meat consumption worldwide continues to rise [1]. As a result, the influx of livestock production worldwide has brought much concern to livestock waste disposal because of the hazard it creates to both health and the environment [2]. Notably, in the Philippines, $80 \%$ of the total livestock production has been accounted from the swine industry [3]. Such a case has also been observed in other parts of the world in Canada [4]. Hence, proper management of hog waste is a necessity.

Rather than simply disposing of hog waste, studies have revealed that it may be utilized as an organic fertilizer [5], [6]. Organic fertilizers produced from hog manure, 
particularly, yield benefits as they are rich in essential nutrients, such as Nitrogen and Phosphorous, which are required by the soil and necessary for plant growth [2]. The study of [5] found that when applying hog manure on hybrid poplars, it has significantly increased their growth and helped improve the chemistry of the soil.

Additionally, when organic fertilizers mainly produced from hog manure are applied at an equivalent rate as synthetic fertilizers, they provide greater crop yields due to the additional organic matter and nutrients [7], [8]. The study of [9], [10] also attested that manure applications improve the nutrients in the soil as well as its structure and therefore grain yields.

Despite the potential of hog manure as an organic fertilizer, it can also give a severe risk if not properly managed [11]. The feces of symptomatic animals, such as hogs, may contain pathogenic bacteria, poses a potential hazard when applied directly on land [2]. Moreover, storing hog manure is also not an option as previous studies have found that Salmonella, a deadly and rapidly-spreading bacterium, can survive in hog waste for 110 days [12], [13]. Hog manure contains the same nutrients in its dried/powdered/coarse form and its liquid/marshy/sticky form. Still, experts have raised concerns about the latter as a higher risk of potential environmental problems may arise, especially in aquatic ecosystems where sediments and nutrient loads may be harmful to biodiversity and human health [5], [14].

In other words, to avoid high risks and gain maximum benefits, hog manure must be processed well and then utilized in producing organic fertilizer that may be used in vegetable farming. Benefits have also been recorded as to the use of organic fertilizers in vegetable farming cultivating vegetables. The study of [15] has found that there has been an increase in the protein content on organically grown potatoes. In another study by [16], they have also noted the improved growth performance of okra (Abelmoschus esulentus) using organic fertilizers mainly derived from animal manures. Similar yields from the use of organic fertilizers have also been noted on other types of vegetables such as bulb onion [17], tomatoes [18], squash [19], and many others.

Most studies focused on the pure hog manure as fertilizer but in this study, it examined the hog waste collected from the beddings in pig pens. The beddings are prepared for hog operation containing the materials of sawdust, soil and salt. Hence, the hog waste is a mixture of such components, hog manure, and hog urine which were utilized as fertilizer for organic vegetable farming.

Hence, the utilization of hog manure as organic fertilizer is beneficial as it helps in hog waste management and, at the same time, it provides better yields in vegetable farming products such as pechay, one of the most renowned vegetables in the Philippines, which plays an essential role in the country's economy and in the nutrition of the Filipino people [20]. Moreover, it also promotes sustainability and cooperation, especially in rural communities where backyard hog raising and vegetable farming are prevalent.

\section{Review of Related Literature}

\section{The need to manage hog wastes}

It has been projected that the world demand for livestock meat will increase by $70 \%$, which signified livestock as one of the fastest-growing subsectors of agriculture [21]. While it is clear that this brings essential contribution in terms of food supply and economic development, the growing number of livestock producers also pose severe concerns as to the number of natural resources used and the accompanying environmental threats [22].

In particular, the challenge of animal waste management has been continually faced by livestock producers because of the nonexistence of either an appropriate place to dispose of the absence of proper technology in re-utilizing animal dung [23]. Even by the start of the 21 st century, many individuals and organizations, both inside and outside of agricultural and agri-food communities, still consider animal manure a waste product that must be disposed of [1]. As a consequence, it has magnified the risk that manure nutrients (e.g., nitrogen, potassium, and phosphorous) and pathogens might flow into the ground as well as surface water, primarily due to leakage from hog production facilities which would then lead to harming livestock, aquatic life, and even human health [24]. Although hog manure has long been proven to be a valuable organic fertilizer [11], there still is a need to manage it properly so as to not over-apply them and thus resulting to serious pollution [25].

\section{Effect of manure application}

Repetitive acts of manure application on agricultural lands can significantly influence the soil quality as a medium for plant growth and as an environmental buffer [26]. Manures, such as liquefied hog manure, are a valuable source of plant micro and macro-nutrients that significantly contribute to substantial yield responses when land-applied [8]. However, excessive application results in excess nutrients such as phosphorous and nitrogen in the soil, increasing the risk of nutrient loss to the environment [27]. Moreover, working with manure is more challenging than commercially available fertilizers. The amounts, forms, and availability of plant nutrients in manure are variable and often not in the right proportions needed by plants [26]. In other words, there is a need to test the manure first and be supplemented with commercial fertilizer to ensure the proper rate and balance of applied nutrients for maximum crop utilization [28]. 


\section{Studies on animal manure utilization in vegetable plants}

From an agronomic perspective, manures can be beneficial as it makes positive impacts on enhancing the soil structure, quality, and productivity. Hence, when the use of inorganic fertilizer is decreased to meet the crops' nutrient needs, it would result in improved crop yields [29] [30]. Animal manures are an essential organic matter and plant nutrients [21]. Reference [31] looked into the effect of organic manure on the yields and growth of okra (Abelmoschus esculentus L.). The study conducted in Sokoto, Nigeri which primarily used sheep, poultry, and cow manure. Results indicated that the application of such had a substantial effect on the number of leaves, plant height, and pod weight of okra. This meant that the application of organic manure to okra plant was effective as evidenced by the positive growth and yield response [16].

Meanwhile, the study of [32] looked into using organic manure as a partial substitute for chemical fertilizers in tomato-radish-pakchoi crop systems. They have discovered that the use of organic manure can meet nutrient needs and maintain vegetable yields. On the other hand, investigating the effects of chicken manure on the growth, quality, and yield of lettuce was the focus of [33]. Results pointed out that lettuce grown with relatively higher amounts of chicken manure exhibited vigorous growth as to the number of leaves, plant height, and leaf area index, as well as to the marketable yield. Moreover, when chicken manure is applied in large quantities, relatively higher amounts of calcium are observed in the lettuce, although no difference in iron content was noted. While [34] amended spent grain and cocoa husk on poultry, cow, and goat manure and studied its effect on tomatoes' growth and fruit yield. By the end of their study, they found out that manures of the previously mentioned animals combined with spent grain and cocoa husk effectively increased Nitrogen and Potassium concentrations, fruit yield, and growth of tomato significantly. They have then recommended that animal manure amended with crop wastes should be used to substitute chemical fertilizer in tomato cultivation.

Apart from the manure derived from the animals mentioned in the previous paragraphs, it may also be used in vegetable cultivation. Land application of hog manure in the liquid form is economical for their disposal and recycling plant nutrients. This practice was seen to increase cereals, legumes, oilseeds, pastures, and vegetables [35]. [36] studied the effects of hog manure on the growth and nutrient uptake of luffa. There are five treatments prepared with varying proportions of chemical fertilizer and hog manure. The results indicated that the yield of the H10C 3 treatment was the highest. The length, radius, and fresh weight of the luffa fruit of the $\mathrm{H} 10 \mathrm{C} 3$ treatment were greater than those of the other treatments.

Additionally, the study of [37] examined the effect of hog dung compost on cabbage's growth and nitrogen composition. Initially, there were no significant differences in terms of productivity. The yield of the 120 Mg ha-1 compost- and chemical fertilizer-treated plots, on the other hand, was higher than that of the $30 \mathrm{Mg}$ ha- 1 and $60 \mathrm{Mg}$ ha- 1 compost-treated plots.

Ultimately, they have concluded that even with the application of $120 \mathrm{Mg}$ ha-1 of compost, no disadvantageous effects on cabbage growth were recorded, but rather, obtained a good yield.

\section{Objectives}

The paper compared the effects of commercial inorganic fertilizer and hog waste organic fertilizer on the growth performance of pechay (Brassica rapa). Specifically, it aims to address the following:

1. Determine the physico-chemical properties of soil and organic hog waste fertilizer as to the following parameters: $\mathrm{pH}$, organic matter, total nitrogen, $\mathrm{P}, \mathrm{K}$, $\mathrm{Na}, \mathrm{Ca}, \mathrm{Mg}, \mathrm{Mn}, \mathrm{Zn}, \mathrm{Cu}, \mathrm{Cr}, \mathrm{Ni}, \mathrm{Pb}$, and $\mathrm{Cd}$.

2. Assess the growth and development of pechay in different treatment groups: T1 - pure soil; T2 - soil with commercial inorganic fertilizer; T3 - 20\% hog waste $+80 \%$ soil; $\mathrm{T} 4-40 \%$ hog waste $+60 \%$ soil; T5 - $60 \%$ hog waste $+40 \%$ soil; T6 - $80 \%$ hog waste + $20 \%$ soil; T7 - $100 \%$ hog waste.

\section{Research Methodology}

\subsection{Materials}

The materials utilized for the experiment were 210 pots $(30 \times 30 \mathrm{~cm}), 5 \mathrm{kgs}$ sifted garden soil, hog waste, urea, complete fertilizer, and pechay seedlings.

\subsection{Soil Sampling}

Soil sampling collection was based on the method used by [38], with modifications being adopted in this study. The exhibition was done in a single set-up, only before the initiation of the experiment. The field is divided into a zig-zag manner; a surface litter was scraped away before digging a V-shaped hole. Each subplot included three independent samples obtained at two distinct depths (from 0 to $15 \mathrm{~cm}, \mathrm{~S} 15$; and from 15 to $30 \mathrm{~cm}, \mathrm{~S} 30$ ). The collected soil was mixed, then a heap was made after that, proceeding to quarter the soil. In choosing the quarters to be sampled, two opposite quarters were discarded. The remaining quarters were mixed and placed in a zip-lock plastic and brought to the laboratory for physico-chemical analyses.

\subsection{Experimental Design}

Following a randomized complete block design 
(RCBD), the field test was performed with seven treatments, replicated thrice, adopted from [39], with few modifications. A total of 210 pots with pechay (Brassica rapa) were used in the experiment. The pots were grouped into three blocks. Each block contains the 70 pots containing the 7 treatments arranged randomly, with 6 inches spacing between the pots. The treatments applied during the entire 30-day period include: T1- pure soil; T2 - soil with CIF; T3- 20\% hog waste; T4 - 40\% hog waste; T5 - 60\% hog waste; T6 - 80\% hog waste; T7 - 100\% hog waste. Each plot received $10 \mathrm{~g}$ of urea in the 1 st week and 2nd week, followed by the application of complete fertilizer in the 3 rd and 4th week of the same amount.

\subsection{Hog Waste Collection}

Hog waste was measured and sampled at the extension project site of the Graduate School, CTU - Moalboal Campus located in the barangays of Balabagon and Bugho, Moalboal Cebu. The hog pen was designed approximately $8 \mathrm{~m} \times 8 \mathrm{~m}$ divided by iron bars into two partitions, hogged with a maximum of 10 . The pen's layer bedding has a depth of $2 \mathrm{ft}$ which is comprised of the following initially with one bag of garden soil, ten sacks of sawdust, and a glass of salt. After four months of use, equivalent to one cycle, the composite mixture is collected and is stored in concrete compost for another five months before using as an organic fertilizer.

\subsection{Laboratory Analysis of Soil Samples and Hog Wastes}

The collected soil and manure samples were brought to the FAST laboratory in Cebu City, Philippines for the analyses of the different physico-chemical parameters: $\mathrm{pH}$, Organic Matter, Nitrogen, Phosphorus using the methods Electrometric, Titrimetry, Kjeldahl Titrimetry, and Colorimetry while Atomic Absorption Spectrophotometry was used to quantify for Potassium, Sodium, Calcium, Magnesium, Manganese, Zinc, Total Copper, Chromium, Nickel, Lead and Cadmium.

\subsection{Statistical Analysis}

All the obtained data were consolidated and transferred to MS Excel for tabulation. Significant differences among treatments were analyzed through one-way ANOVA, and further analyzed using the Post Hoc test for significant ANOVA results.

\section{Results and Discussions}

\subsection{Physico-Chemical Analyses of Soil and Hog Waste}

The results of this study revealed that the collected soil before the mixture with organic hog waste fertilizer showed the following parameters (Table 1). Identifying the physico-chemical properties of the soil is essential to note the components for optimum plant yield. According to [40], pechay can grow from mid to low elevations of soil the entire year but grows best under excellent conditions.

Table 1. Physico-chemical properties of soil and hog waste used in the study

\begin{tabular}{|c|c|c|}
\hline Physico Chemical Analyses & Soil & Hog Waste \\
\hline $\mathrm{pH}$ & $7.41 @ 20.2^{\circ} \mathrm{C}$ & $7.98 @ 21.2^{\circ} \mathrm{C}$ \\
\hline Organic matter, $\%$ & 13.30 & 3.10 \\
\hline Total Kjeldahl Nitrogen, $\%$ & 0.274 & 0.152 \\
\hline${ }^{\beta}$ Phosphorus, $\mathrm{mg} / \mathrm{Kg}$ & 286 & 264 \\
\hline${ }^{\beta}$ Potassium, $\mathrm{mg} / \mathrm{Kg}$ & 0.436 & 108 \\
\hline${ }^{\beta}$ Sodium, $\mathrm{mg} / \mathrm{Kg}$ & 368 & 2.69 \\
\hline${ }^{\beta}$ Calcium, $\mathrm{mg} / \mathrm{Kg}$ & 4.4 & 0.214 \\
\hline${ }^{\beta}$ Magnesium, $\mathrm{mg} / \mathrm{Kg}$ & 0.209 & 1408 \\
\hline${ }^{\beta}$ Manganese, $\mathrm{mg} / \mathrm{Kg}$ & 0.377 & 39.6 \\
\hline${ }^{\beta}$ Zinc, $\mathrm{mg} / \mathrm{Kg}$ & 352 & 30.2 \\
\hline${ }^{\beta}$ Total Copper, $\mathrm{mg} / \mathrm{Kg}$ & 110 & Less than $4.0^{* *}$ \\
\hline${ }^{\beta}$ Chromium, $\mathrm{mg} / \mathrm{Kg}$ & Less than $4.0^{* *}$ & 11.8 \\
\hline${ }^{\beta}$ Nickel, $\mathrm{mg} / \mathrm{Kg}$ & Less than $4.0^{* *}$ & 12.5 \\
\hline${ }^{\beta}$ Lead, $\mathrm{mg} / \mathrm{Kg}$ & 5.56 & Less than $0.40^{* *}$ \\
\hline${ }^{\beta}$ Cadmium, $\mathrm{mg} / \mathrm{Kg}$ & Less than $0.40^{* *}$ & \\
\hline
\end{tabular}


The soil analysis showed a $\mathrm{pH}$ of 7.41, which is within the neutral spectrum. However, the literature suggests that pechay grows best at a slightly acidic medium with $\mathrm{pH}$ 5.5-6.5 during the dry season [40]. Hence, it would be advantageous to apply fertilizers or organic compounds to buffer the collected soil into a lower $\mathrm{pH}$ for optimum plant growth. Thus, soil $\mathrm{pH}$ is considered a master variable in soils since it controls various biochemical processes [41], [42] important for plant development, setting the proper soil $\mathrm{pH}$ to match the preferred $\mathrm{pH}$ of pechay is crucial for best results [43].

The study of Swine manure production and Nutrient Content by [44] results presented that Ammonium was present in the soil. Ammonium turns to ammonia at a $\mathrm{pH}$ level higher than 6.5. They use more alkaline or less acid to increase the $\mathrm{pH}$, which increases the amount of ammonia and decreases the ammonium. Results revealed that most manure got a $\mathrm{pH}$ level nearer to 7.0. Therefore, the ammonium and ammonia are both present. The plant nutrients are formed from the feeds, medications, water, and supplements fed to the animals. Thus, utilizing swine manure as a fertilizer for crops can give a portion, or all, of the plant nutrients.

The collected soil has $13.30 \%$ organic matter and fairly high phosphorus values, $286 \mathrm{mg} / \mathrm{kg}$, sodium, $368 \mathrm{mg} / \mathrm{kg}$, and zinc, $352 \mathrm{mg} / \mathrm{kg}$. Organic matter is developed from the partial or well-decomposed residues of organic biomasses. It is needed in a fertile soil for it gives plant nutrients, protects soil $\mathrm{pH}$, and enhances water holding capacity and aeration. Hence, it is beneficial for soil conditions to have a high organic matter percentage [45], [46].

Moreover, results showed that collected soil has low measure of total nitrogen, $0.27 \%$, potassium, $0.44 \mathrm{mg} / \mathrm{kg}$, magnesium, $0.21 \mathrm{mg} / \mathrm{kg}$, and manganese $0.38 \mathrm{mg} / \mathrm{kg}$. Only trace amounts of chromium, nickel, and cadmium were present. With the limited supply of macro and micronutrients present in the collected soil, fertilizers may enhance the soil's condition. Generally, there are 17 essential elements necessary for plant growth, including Carbon, hydrogen, oxygen, nitrogen, phosphorus, potassium, calcium, magnesium, sulfur, iron, manganese, zinc, copper, boron, molybdenum, chlorine, and nickel. Limitation of any of these nutrients would result in decreased crop production. Seeing that most of the listed essential nutrients are present in the collected soil indicates that the soil sample would be a good candidate for growing pechay. Among these essential nutrients, the primary macronutrients, Nitrogen, Potassium, and Phosphorus, are needed in the most quantities and are most likely to be in short supply in agricultural soils. And as shown (Table 1), the collected pre-mixed soil had fairly high phosphorus values, which notes the availability of the nutrient in the soil. Secondary macronutrients are those needed in smaller amounts and are typically found to be sufficient in soil; hence, they do not pose a limitation for plant growth. Then, the micronutrients or trace nutrients are those needed in small amounts and, if present in excess, would be toxic to plants [45], [47], [48].

Although there is limited literature regarding the soil physico-chemical properties and conditions best suitable for optimum growth of pechay, various literature have noted the use of organic fertilizers to boost soils condition for better plant results [20], [39], [49], [50].

The hog waste collected showed the following parameters (Table 1). Analysis showed a $\mathrm{pH}$ of 7.98 , leading towards a basic $\mathrm{pH}$, and is slightly higher than pure soil. This may not be the best $\mathrm{pH}$ condition for growing pechay since these plants prefer a slightly acidic medium [40]. Such soil $\mathrm{pH}$ significantly affects the availability of plant nutrients and microbial activity [41], [42], [45]. Although the basicity of the collected soil may not provide the best condition for the crop, it may be advantageous for plant growth. Since at low $\mathrm{pH}$, essential plant macronutrients are less available, and micronutrients tend to become more soluble and potentially toxic at low $\mathrm{pH}$ values [45], [51].

Organic hog waste material has a high value of manganese, $1408 \mathrm{mg} / \mathrm{kg}$, phosphorus, $264 \mathrm{mg} / \mathrm{kg}$, potassium, $252 \mathrm{mg} / \mathrm{kg}$, and sodium, $108 \mathrm{mg} / \mathrm{kg}$ essential nutrients for optimum plant growth. Zinc and copper are lower in value at $39.6 \mathrm{mg} / \mathrm{kg}$ and $30.2 \mathrm{mg} / \mathrm{kg}$, respectively, compared to pure soil. The addition of organic hog waste to pure soil increases the soil's organic matter and the release of its nutrients. They also serve as a slow-reservoir for plant macronutrients and provide additional supply for plant micronutrient nutrition which aids in producing vegetables.

Moreover, the small amount of heavy metals, lead, zinc, and copper values (Table 2) of organic hog waste may suggest the advantage on the utilization of the material. This may limit crop contamination, leading to environmental pollution. Even if these are considered micronutrients, the prolonged application may lead to plant toxicity if taken in large amounts and might lead to soil contamination [49]. The availability of micronutrients is also related to soil $\mathrm{pH}$ since, with increasing $\mathrm{pH}$, micronutrient availability is reduced [52]. However, most of the micronutrients absorbed from the soil contained in leaves which compose the majority of plant parts for pechay. Hence, even if the organic hog waste has basic $\mathrm{pH}$, applying the organic material to pure neutral soil may buffer the total soil $\mathrm{pH}$ towards the preferred soil condition for pechay growth. 
Table 2. Effect of pure soil, commercial fertilizer and hog waste treatments on crop length, width, number of leaves, root length, and weight

\begin{tabular}{|c|c|c|c|c|c|c|c|c|}
\hline Parameters & T1 & T2 & T3 & T4 & T5 & T6 & T7 & P-Value \\
\hline $\begin{array}{c}\text { Average height } \\
\text { gain /plant (cm) }\end{array}$ & $79.27^{\mathrm{ab}}$ & $88.73^{\mathrm{ab}}$ & $95.93^{\mathrm{ab}}$ & $88.30^{\mathrm{ab}}$ & $108.27^{\mathrm{b}}$ & $85.53^{\mathrm{ab}}$ & $66.60^{\mathrm{a}}$ & $0.000^{*}$ \\
\hline $\begin{array}{c}\text { Average leaf width } \\
\text { gain (cm) }\end{array}$ & $34.83^{\mathrm{a}}$ & $60.70^{\mathrm{b}}$ & $51.07^{\mathrm{ab}}$ & $37.90^{\mathrm{a}}$ & $112.07^{\mathrm{b}}$ & $105.40^{\mathrm{ab}}$ & $64.13^{\mathrm{a}}$ & $0.000^{*}$ \\
\hline $\begin{array}{c}\text { Average no. of } \\
\text { leaves/plant }\end{array}$ & $8.20^{\mathrm{a}}$ & $9.47^{\mathrm{ab}}$ & $9.67^{\mathrm{ab}}$ & $9.23^{\mathrm{ab}}$ & $11.07^{\mathrm{b}}$ & $13.40^{\mathrm{c}}$ & $7.47^{\mathrm{a}}$ & $0.000^{*}$ \\
\hline $\begin{array}{c}\text { Average Weight / } \\
\text { plant (g) }\end{array}$ & $12.97^{\mathrm{a}}$ & $74.79^{\mathrm{bc}}$ & $22.80^{\mathrm{a}}$ & $40.60^{\mathrm{ab}}$ & $86.67^{\mathrm{c}}$ & $98.13^{\mathrm{c}}$ & $33.86^{\mathrm{a}}$ & $0.024^{*}$ \\
\hline $\begin{array}{c}\text { Ave. root length/ } \\
\text { plant (cm) }\end{array}$ & $161.03^{\mathrm{a}}$ & $177^{\mathrm{a}}$ & $246.97^{\mathrm{b}}$ & $242.70^{\mathrm{b}}$ & $195.73^{\mathrm{ab}}$ & $241.40^{\mathrm{b}}$ & $145.47^{\mathrm{a}}$ & $0.000^{*}$ \\
\hline $\begin{array}{l}* \\
\text { at significant }(\mathrm{p}<0.05) \text {. Treatment means within the same row having the same superscripts are not significantly different from each other }\end{array}$ \\
\hline
\end{tabular}

Laboratory analysis shows that organic hog waste material has higher $\mathrm{pH}$, potassium, and manganese than pure soil. However, pechay is known to grow in any soil. They are known to grow better in light, sandy-loam, well-drained soil with a pH level of 5.4-6.7 [53], which is relatively lower than the obtained $\mathrm{pH}$ from hog waste material. The basic $\mathrm{pH}$ of hog waste may pose a limitation for nutrient availability for plants. In highly alkaline soil, there is less availability of phosphorus and most micronutrients. On the other hand, macronutrients are maximally available for plants at $\mathrm{pH}$ 6.5-7.5 [54], close to the obtained hog waste $\mathrm{pH}$. In this context, since the collected pure soil has lower $\mathrm{pH}$ than hog waste, organic fertilizer becomes desirable.

In the study conducted by [55], they reported a reduction in exchangeable acidity, improvement of soil $\mathrm{pH}$. Increased nutrient status of soil in terms of organic matter, total nitrogen, phosphorus, and calcium contribute to the application of pig waste. Hence, this highlights the importance of hog waste application for soil improvement.

In addition to nutrient availability for plants, swine manure also has innate nutrient content, which may vary according to the animals' age, ratio, temperature, and methods for manure collection. According to [44], Hog waste contains the 13 essential plant nutrients necessary for plant growth. Based on their collected data on the Nutrient content of manure as excreted (from ASAE Standard D384.1, 1998) showed that the collected swine manure has Ammonium nitrogen, 28.6\%, Organic Nitrogen, 22.7\%, Phosphorus, 40.4\%, Potassium, 34.5\%, Calcium, $32.6 \%$, Magnesium, $6.9 \%$, sulfur, $7.5 \%$, manganese, $0.19 \%$, Copper $0.12 \%$, and Zinc, $0.49 \%$. The available nutrients come from feeds, supplements, medications, and water consumed by the animal. The storage and collection play a role in the nutrient content of fresh swine manure, where anaerobic decomposition occurs in most storages. Anaerobic bacteria degrade the volatile solids in the waste hence converting organic nitrogen to ammonium nitrogen, and over time this converts to ammonia which can be lost in the atmosphere [44]. This might explain why total nitrogen is less in hog waste material compared to pure soil.

\subsection{Growth performance of pechay (Brassica Rapa)}

The result of the application of hog waste materials on the growth of pechay showed that among the treatments with mixtures of soil and hog waste, Treatment 5 had the highest plant height among the treatments with an average height gain of $108.27 \mathrm{~cm}$. It is significantly different from Treatment 3, comparable to commercial inorganic fertilizer and other treatments. The lowest stem length was obtained by Treatment 7, with $66.60 \mathrm{~cm}$, followed by the Negative control treatment, $79.27 \mathrm{~cm}$.

In terms of stem width growth, treatments obtained similar results as that of the plant height parameter. Among the treatments, T5 also had the largest stem width growth with $112.07 \mathrm{~cm}$ (p-value 0.000 ), while Negative treatment had the smallest width growth difference, 34.83 $\mathrm{cm}$. T5 is significantly higher than $\mathrm{T} 7$ and $\mathrm{T} 1$ but comparable to commercial inorganic fertilizer and other treatments.

The variable growth of pechay (Brassica rapa) in different hog waste treatments indicates the potential of the organic material as a component of growing medium for crops. The difference in pechay (Brassica rapa) growth may be attributed to the differences in the treatments' chemical properties. Pure hog waste produces a low yield in terms of crop length compared to treatment with a mixture of hog waste and pure soil. Pure hog waste (treatment 7) may present toxicity to plants due to excess or limited nutrient availability. As shown in Table 1, hog waste components are lower in nutrient composition than pure soil. Also, excessive application of manure [35] increases the leaching of nitrates, phosphorus, and magnesium, essential nutrients for plant growth. Compared to hog waste-soil mixture, which may balance the soil's $\mathrm{pH}$ and nutrient availability, producing the most yield among the treatments even exceeding the positive control. It indicates that organic hog waste as fertilizer can match commercial inorganic fertilizers in increasing plant height and width.

In addition, the results showed that Treatment $6(80 \%$ Hog waste $+20 \%$ soil) obtained the highest number of leaves and plant weight. Negative control treatment (soil without fertilizer) had the smallest number of leaves 
(Table 2), and Treatment 7 had the least total plant weight yield. The low number of leaves of the negative control treatment may be attributed to the little availability of micronutrients present in pure soil (Table 1), as reflected in leaf production. With the plant of interest, Brassica rapa, its leaves are a significant portion of the whole plant since it is edible. The results obtained showed that the addition of organic hog waste fertilizers produced the optimum number of leaves as seen in Treatment 6 , followed by Treatment 5 with the second-highest number of leaves produced compared to both control treatments. Among the treatments, both Treatments 1 (pure soil) and T7 (100\% hog waste) had the least number of leaves, counting around 8 and 7, respectively, and this may be due to the limitation of micronutrients (Table 1) and excess of heavy metals (Table 1), respectively.

Literature reports the increase of leaf or seed concentration of sodium, potassium, and phosphorus [35], [56] with the addition of swine manure. With the increase of plant nutrient concentrations, swine manure was shown to increase crop quality compared with inorganic fertilizers. It can explain the results obtained (Table 2), where Treatment 6 with $80 \%$ hog waste $+20 \%$ soil presented with the highest number of leaves compared to the positive control Treatment 2 (inorganic fertilizer), 5. Also, treatment 7 with $100 \%$ hog waste is one with the least number of leaves. Similarly, in Treatment 1, such decline may be due to the excess of nutrients present. According to [57] the increased rate of swine manure application increased the plant levels of nitrogen, potassium, and phosphorus along with the decline of recovery of plant nutrients, which may leech off potential pollutants to surface and ground waters [35], [58].

In terms of root length, results obtained showed that the positive control, Treatment $3(20 \%$ hog waste $+80 \%$ soil $)$, had the highest measurement with $246.97 \mathrm{~cm}$, followed by Treatment $6(80 \%$ hog waste $+40 \%$ soil $)$ with $241.40 \mathrm{~cm}$. Treatment 7 (100\% hog waste $+0 \%$ soil) had the lowest root length measure with $145.47 \mathrm{~cm}$, followed by the negative control, Treatment 1 (soil without fertilizer) with $161.03 \mathrm{~cm}$.

Soil $\mathrm{pH}$ plays a role in plant root growth, where at low soil $\mathrm{pH}$ values, $\mathrm{H}+$ and Aluminum ions are common in soil solution, which can be toxic to plant roots. In contrast, at low or high soil $\mathrm{pH}$, various micronutrients essential for plants become unavailable, in which other elements were converted to toxic forms for plant roots [42]. Hence, with the composition of hog waste material (Table 1), which has a slightly basic $\mathrm{pH}$, this may limit the availability of plant micronutrients for root growth. Hence among the hog waste treatments, the treatment with the lowest hog waste percentage, Treatment $3(20 \%$ hog waste $+80 \%$ soil), obtained the highest crop root length.

The presented results were close to the results of the Comparative Study on the Effects of Organic and Inorganic fertilizer conducted by [59], which revealed that organic fertilizer (sawdust, poultry droppings, and cow dung: $500 \mathrm{~kg}$ ha-1) significantly $(\mathrm{p}<0.5)$ higher effect on all the parameters studied. When compared to inorganic fertilizer, the percentage difference obtained for organic fertilizer was similarly significantly larger for all plant samples.

\section{Conclusion}

The results showed that the addition of organic hog waste fertilizer greatly enhanced the growth and yield performance of pechay (Brassica rapa). Specifically, the application of $60 \%$ to $80 \%$ of hog waste material to pure soil yields the highest values for plant height, width, weight, and the number of leaves, respectively. Hence, organic hog waste fertilizer aid matched crop-nutrient demand with nutrient supply and recommended optimal pechay production.

\section{Acknowledgement}

The authors would like to thank Cebu Technological University for the funds provided to support this project.

\section{REFERENCES}

[1] Laguë, C., \& Eng, P. "Challenges and Opportunities in Livestock Manure Management”, 2020. DOI: 10.1.1.493.2066

[2] Akinnuli, B. O., \& Bodunde, O. P. "Development of a charcoal-fuelled dryer for the production of organic fertilizer from hog waste", African Journal of Science, Technology, Innovation and Development, Vol. 9 No. 2, pp. 215-221, 2017. DOI: 10.1080/20421338.2017.1311158

[3] Lapus ZM. Swine production in the Philippines. March 2009.

[4] AAI. "Environmental and health problems in livestock production: pollution on the food system." Agribusiness Accountability Initiative 410: 2013, pp. 314-335.

[5] Lafleur, Benoit, et al. "Effects of hog manure application on the nutrition and growth of hybrid poplar (Populus spp.) and on soil solution chemistry in short-rotation woody crops." Agriculture, ecosystems \& environment. Vol. 155, pp. 95-104, 2012. DOI: 10.1016/j.agee.2012.04.002

[6] Nikiéma, P., Buckley, K. E., Enns, J. M., Qiang, H., \& Akinremi, O. O. "Effects of liquid hog manure on soil available nitrogen status, nitrogen leaching losses and wheat yield on a sandy loam soil of western Canada", Canadian Journal of Soil Science, Vol. 93, No. 5, pp. 573-584, 2013. doi.org/10.4141/cjss2012-070

[7] Buckley, K. E., Therrien, M. C., \& Mohr, R. M. Agronomic performance of barley cultivars in response to varying rates 
of swine slurry. Canadian Journal of Plant Science, Vol. 91, No. 1, pp. 69-79, 2011. doi.org/10.4141/cjps09032

[8] Mooleki, S. P., Schoenau, J. J., Hultgreen, G., Wen, G., \& Charles, J. L. "Effect of rate, frequency and method of liquid swine manure application on soil nitrogen availability, cropperformance and $\mathrm{N}$ use efficiency in east-central Saskatchewan" Canadian Journal of Soil Science, Vol. 82, No. 4, pp. 457-467, 2002. doi.org/10.4141/S01-057

[9] Zhong, W., Gu, T., Wang, W., Zhang, B., Lin, X., Huang, Q., \& Shen, W. "The effects of mineral fertilizer and organic manure on soil microbial community and diversity" Plant and soil, Vol. 326, No. 1-2, pp. 511-522, 2010. doi:10.1007/s11104-009-9988-y

[10] Liu, E., Yan, C., Mei, X., He, W., Bing, S. H., Ding, L., \& Fan, T. "Long-term effect of chemical fertilizer, straw, and manure on soil chemical and biological properties in northwest China" Geoderma, Vol. 158, No. 3-4, pp. 173-180, 2010. doi.org/10.1016/j.geoderma.2010.04.029

[11] Leung, K., \& Topp, E. "Bacterial community dynamics in liquid swine manure during storage: molecular analysis using DGGE/PCR of 16S rDNA”, FEMS Microbiology Ecology, Vol. 38, No. 2-3, pp. 169-177, 2001 doi.org/10.1111/j.1574-6941. 2001.tb00895.x

[12] Arrus, K. M., Holley, R. A., Ominski, K. H., Tenuta, M., \& Blank, G. "Influence of temperature on Salmonella survival in hog manure slurry and seasonal temperature profiles in farm manure storage reservoirs", Livestock Science, Vol. 102 No. 3, pp. 226-236, 2006. doi.org/10.1016/j.livsci.200 6.03 .021

[13] Hutchison, M. L., Walters, L. D., Avery, S. M., Munro, F., \& Moore, A. "Analyses of livestock production, waste storage, and pathogen levels and prevalences in farm manure" Applied and Environmental Microbiology. Vol. 71, No. 3, pp. 1231-1236, 2005. doi/10.1128/AEM.71.3.12311236.2005

[14] Carpentier, C. L., Speir, J., Bowden, M. A., Ervin, D., Pérez Espejo, R., McElfish, J., \& Whitehouse, T. "Comparative Standards for Intensive Livestock Operations in Canada, Mexico, and the United States", 2003.

[15] Maggio, A., Carillo, P., Bulmetti, G. S., Fuggi, A., Barbieri, G., \& De Pascale, S. "Potato yield and metabolic profiling under conventional and organic farming" European Journal of Agronomy, Vol. 28, No. 3, pp. 343-350, 2008. doi.org/10.1016/j.eja.2007.10.003

[16] Uka, U. N., Chukwuka, K. S., \& Iwuagwu, M. "Relative effect of organic and inorganic fertilizers on the growth of okra [Abelmoschus esculentus (L.) Moench]" Journal of Agricultural Sciences, Belgrade, Vol. 58, No. 3, pp. 159-166, 2013. doi.org/10.2298/JAS1303159U

[17] Lee, J. "Effect of application methods of organic fertilizer on growth, soil chemical properties and microbial densities in organic bulb onion production", Scientia Horticulturae, Vol. 124, No. 3, pp. 299-305, 2010. doi.org/10.1016/j.scienta.2010.01.004

[18] Kapoulas, N., Ilić, Z. S., Đurovka, M., Trajković, R., \& Milenković, L. "Effect of organic and conventional production practices on nutritional value and antioxidant activity of tomatoes", African Journal of Biotechnology.
Vol. 10 No. 71, pp. 15938-15945. 2011. doi.org/10.5897/AJB.9000177

[19] Sarhan, T. Z., Mohammed, G. H., \& Teli, J. A. "Effect of bio and organic fertilizers on growth, yield and fruit quality of summer squash", Sarhad J. Agric Vol. 27, No. 3, pp. 377-383, 2011. http://www.aup.edu.pk/sj_pdf/effect $\% 2 \ldots$

[20] Gonzales, L., \& Aban, M. "Response of Pechay (Brassica napus L.) to Different Levels of Compost Fertilizer", International Journal of Scientific and Research Publications Vol. 5, No. 2, pp. 1-4, 2015. doi $=10.1 .1 .736 .8785$

[21] Belete, E., \& Ayza, A. "A review on alternative technologies to manage manure: Cost effective and environmentally beneficial", Livestock Research for Rural Development Vol. 27, No. 10, 2015 http://www.lrrd.org/lrrd27/10/bele27192.htm

[22] Alexandratos, N., and J. Bruinsma. "World agriculture towards 2030/2050: the 2012 revision" ESA Working Paper No. 12-03, 2012. DOI: 10.22004/ag.econ.288998

[23] Asrat, A., Zelalem, Y., \& Ajebu, N. Production, utilization and marketing of milk and milk products: Quality of fresh whole milk produced in and around Boditti, Wolaita, South Ethiopia. LAP LAMBERT Academic Publishing, Deutschland, Germany, Vol. 27, Article 192. pp. 75-76, 2014. http://lrrd.cipav.org.co/lrrd27/10/bele27192.htm

[24] Key, N., McBride, W. D., Ribaudo, M., \& Sneeringer, S. "Trends and developments in hog manure management: 1998-2009" USDA, Economic Research Service, Economic Information Bulletin No.81, 2011.https://papers .ssrn.com/sol3/papers.cfm?abstract_id $=2981722$

[25] Ribaudo, M., Kaplan, J. D., Christensen, L. A., Gollehon, N., Johansson, R., Breneman, V. E. \& Peters, M. "Manure management for water quality costs to animal feeding operations of applying manure nutrients to land" USDA-ERS Agricultural Economic Report, No. 824, 2003. doi.org/10.2139/ssrn. 757884

[26] Schoenau, J.J. "Benefits of long-term application of manure" Advances in Pork Production, Vol. 17, p. 153, 2006. doi.10.1.1.556.6312

[27] Stumborg, C. M., Schoenau, J.J. \& Qian, P. "Phosphorus loading and environmental analysis in manured Saskatchewan soils", In Soils and Crops Workshop, February 2005. https://harvest.usask.ca/handle/10388/9475

[28] Schoenau, J.J., Mooleki, S.P., Malhi, S. S., \& Hultgreen, G. "Strategies for maximizing crop recovery of nutrients applied as liquid swine manure", In Proceedings of Great Plains Soil Fertility Conference. Kansas State University, March, pp. 2-3, 2004.

[29] Siddiqui, Z.A. "Effects of plant growth promoting bacteria and composed organic fertilizers on the reproduction of Meloidogyne incognita and tomato growth" Bioresource technology, Vol. 95, No. 2, pp. 223-227, 2004. doi.org/10.1016/j.biortech.2003.01.002

[30] Walker, D. J., \& Bernal, M. P. "The effects of olive mill waste compost and poultry manure on the availability and plant uptake of nutrients in a highly saline soil", Bioresource technology, Vol. 99, No. 2, pp. 396-403, 2008. doi.org/10.1016/j.biortech.2006.12.006 
[31] Tiamiyu, R. A., Ahmed, H. G., \& Muhammad, A. S. "Effect of sources of organic manure on growth and yields of okra (Abelmoschus esculentus L.) in Sokoto, Nigeria", Nigerian Journal of Basic and Applied Sciences, Vol. 20, No. 3, pp. 213-216, 2012. https://www.ajol.info/index.php/njbas/artic le/view/85346

[32] Lu, H. J., Ye, Z. Q., Zhang, X. L., Lin, X. Y., \& Ni, W. Z. "Growth and yield responses of crops and macronutrient balance influenced by commercial organic manure used as a partial substitute for chemical fertilizers in an intensive vegetable cropping system", Physics and Chemistry of the Earth, Parts A/B/C, Vol. 36, No. 9-11, pp. 387-394, 2011. /doi.org/10.1016/j.pce.2010.03.030

[33] Masarirambi, M. T., Dlamini, P., Wahome, P. K., \& Oseni, T. O. "Effects of chicken manure on growth, yield and quality of lettuce (Lactuca sativa L.) 'Taina' under a lath house in a semi-arid sub-tropical environment" Agriculture and Environmental Science, Vol. 12, No. 3, pp. 399-406, 2012. https://www.cabdirect.org/cabdirect/abstract/201231 81896

[34] Ojeniyi, S. O., Awodun, M. A., \& Odedina, S. A. "Effect of animal manure amended spent grain and cocoa husk on nutrient status, growth and yield of tomato" Middle-East Journal of scientific research, Vol. 2, No. 1, pp. 33-36, 2007. doi:10.1.1.555.1754

[35] Choudhary, M., Bailey, L. D., \& Grant, C. A. "Review of the use of swine manure in crop production: effects on yield and composition and on soil and water quality", Waste Management \& Research, Vol. 14, No. 6, pp. 581-595, 1996. doi.org/10.1177/0734242X9601400606

[36] Lin, C.H. \& Lin, L.F. Effects of hog manure on the growth and nutrient uptake of luffa, 2001. https://worldveg.tind.io/record/29359/

[37] Chung, R. S., Chen, Z. S., \& Huang, S. L. "Growth and nitrogen composition of Cabbage under high application rate of hog dung compost. Bio- Agriculture, Vol. 44, No. 4, pp. 263-271, 2006. DOI: 10.6578/TJACFS.2006.031

[38] Parewa, Hanuman \& Jain, Lokesh \& Mahajan, Gopal \& Bhimawat, B.S. "Soil Health Card: A Boon for the Indian Farmers", Indian Journal of Plant and Soil. Vol. 3, pp. 77-81, 2016. DOI: 10.21088/ijps.2348.9677.3216.3.

[39] Bandera, A. "Inorganic Fertilizers (Ground and Foliar Application) and Organic Fertilizer: Their Effects on the Growth and Yield of Pechay (Brassica napus L. subsp. chinensis var. Black Behi)", International Journal of Research Studies in Agricultural Sciences (IJRSAS), pp. 38-55, 2020. DOI: http://dx.doi.org/10.20431/2454-6224.0 606005

[40] Maghirang, R. G., and M. B. Miranda. "Pechay production guide." Information Bulletin (Philippines) 2000. https://agris.fao.org/agris-search/search.do?recordID $=\mathrm{PH} 2$ 002000134

[41] Oshunsanya, Suarau Odutola. "Introductory chapter: relevance of soil $\mathrm{pH}$ to agriculture." Soil $\mathrm{pH}$ for Nutrient Availability and Crop Performance. IntechOpen, 2018. DOI: 10.5772/intechopen.82551

[42] Neina, D. "The Role of Soil pH in Plant Nutrition and Soil Remediation" Applied and Environmental Soil Science, 2019. doi.org/10.1155/2019/5794869
[43] Loss, A., Couto, R., Brunetto, G., Da Veiga, M., Toselli, M., \& Baldi, E. "ANIMAL MANURE AS FERTILIZER: CHANGES IN SOIL ATTRIBUTES, PRODUCTIVITY AND FOOD COMPOSITION" International Journal of Research, pp. 307-331, 2019. https://doi.org/10.29121/gran thaalayah.v7.i9.2019.615

[44] Chastain, J., Camberato, J., Albrecht, J., \& Adams III, J. Swine Manure Production and Nutrient Content. CAMM Poultry Chapter 3A, pp. 3-18, 2003.

[45] Parikh, S., \& James, B. "Soil: The Foundation of Agriculture" Nature Education Knowledge, Vol. 3, No. 10, page 2, 2012.http://www.nature.com/scitable/knowledge/li brary/soil-the-foundation-of-agriculture- 84224268

[46] Mitchell, J., Gaskell, M., Smith, R., Fouche, C., \& Koike, S. "Soil Management and Soil Quality for Organic Crops" Division of Agriculture and Natural Resources, 2002. DOI:10.3733/ucanr.7248

[47] Troeh, F., \& Thompson, L. "Soils and Soil Fertility" 5th ed. Oxford University Press, 1993. https://library.wur.nl/Web Query/titel/1762424

[48] Subbarao, G., Ito, O., Berry, W., \& Wheeler, R. "Sodium A functional plant nutrient" Critical Reviews in Plant Sciences, pp. 391-416, 2003. doi.org/10.1080/0735268039 0243495

[49] Vallejera, C., Asio, V., Tulin, A., \& Dorahy, C. "Nutrient Analysis, Decomposition, and Nitrogen Mineralization of Various Organic Amendments Used for Pechay Production" Annals of Tropical Research, Vol. 36, No.1, pp. 88-101, 2014.https://cdn.annalsoftropicalresearch.com/wp-content/ uploads/pdf_files/Volume36No.1/7.pdf

[50] Balayo,S. "Growth and Yield Performance of the Different Varieties of Pechay (Brassica chinensis) as Affected by the Different Organic Fertilizers under MSU-Marawi Condition", International Journal of Humanities and Social Sciences, pp. 103-111, 2015.

[51] Brady, N., \& Weil, R. "The Nature and Properties of Soil" 14th ed. Prentice Hall, 2008. https://hero.epa.gov/hero/inde x.cfm/reference/details/reference_id/3227875

[52] Umesh, G., Kening, W., \& Siyuan, L. Micronutrients in Soils, Crops, and Livestock. Earth Science Frontiers, pp. 110-125, 2008. doi.org/10.1016/S1872-5791(09)60003-8

[53] Cresastre. Agriculture on the Move, lets plant something. wordpress: https://letsplantsomething.wordpress.com/2010 /08/13/pechay-cultural-management, Retrieved July 7, 2021.

[54] Chowdhury, S., Bolan, N., Farrell, M., Sarkar, B., Sarker, J. R., Kirkham, M. B., \& Kim, G. H. "Role of cultural and nutrient management practices in carbon sequestration in agricultural soil" Advances in agronomy, pp. 131-196, 2021.

[55] Stevens, C., Ugese, F., \& Baiyeri, K. "Effect of pig manure on growth and productivityof twenty accessions of moringa oleifera in nigeria" Journal of Tropical Agriculture, Food, Environment and Extension, pp. 19-26. 2018. DOI: 10.4314/as. v17i3.4

[56] Sutton, A. L., Nelson, D. W., Hoff, J. D. \& Mayrose, V. B. "Effects of injection and surface applications of liquid 
swine manure on corn yield and soil composition" Journal of Environmental Quality. Vol. 11, pp. 468-472, 1982. https://doi.org/10.2134/jeq1982.00472425001100030030x

[57] Burns, J., Westerman, P., King, L., Overcash, M., \& Cummings, G. "Swine manure and lagoon effluent applied to a temperate forage mixture: I. Persistence, yield,quality, and elemental removal" Journal of environmental quality, pp. 99-105, 1987.https://doi.org/10.2134/jeq1987.0047242 $5001600020003 x$
[58] Pfarr, C., ilson, M., Coulter, J., \& Fernandez, F. "Liquid swine manure as a side dressed nitrogen source for corn" Agronomy Journal, pp. 5206-5221, 2020 https://doi.org/10.1002/agj2.20380

[59] Mofunanya, A.A.J, Ebigwai, J.K., Bello, O.S., Egbe, A.O. "Comparative Study of the Effects of Organic and Inorganic Fertilizer on Nutritional Composition of Amaranthus spinosus L.," Asian Journal of Plant Sciences, Vol. 14, No.1, pp. 36-37, 2015. DOI:10.3923/ajps.2015.34.39 